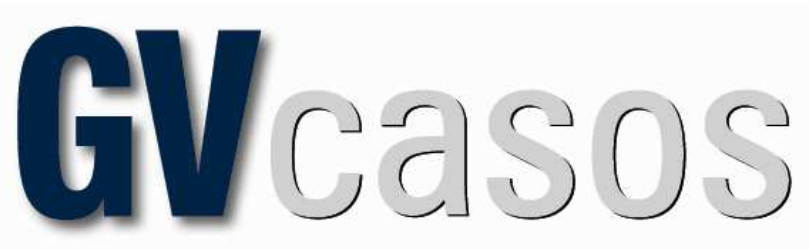

Rev. Bras. de Casos de Ensino em Administração

ISSN 2179-135X

\title{
O MÉTODO DO CASO E A ORQUESTRA
}

\section{Paulo Mattos de Lemos \\ Fundação Getulio Vargas - RJ}

O método do caso surgiu no início do século passado na escola de negócios da universidade de Harvard, derivado dos casos de jurisprudência desenvolvidos na sua escola de direito.

O caso deve tratar de um problema real, trazido para a sala de aula de modo a que os alunos possam se exercitar no processo de chegar a uma solução, aplicando corretamente os conceitos teóricos pertinentes.

Os alunos devem receber o caso com antecedência, estudar estes conceitos teóricos e desenvolver a sua solução. Na sala de aula eles devem coletivamente desenvolver uma solução.

O professor também precisa se preparar previamente, revisitando os conceitos teóricos e desenvolvendo a sua solução para o caso, que deverá pontuar o aprendizado destes conceitos pelos alunos.

O escopo da preparação de um professor que dá aulas expositivas, sem perguntas, é muito mais restrito do que o de um professor que propõe debates em sala. O professor que utiliza o método do caso deve ter um escopo de preparação ainda mais amplo, para dar conta de um espectro ainda mais amplo de possíveis questões pelos alunos.

Na sala de aula, o professor com o método do caso deve atuar de modo similar ao maestro conduzindo uma orquestra. O maestro faz com que cada instrumento apareça de acordo com a sua

\section{CFGV-EAESP/RAE 2011}

Todos os direitos reservados. Permitidas a citação e a reprodução parcial ou total, desde que identificada a fonte. Em caso de dúvidas, consulte a Redação: gvcasos.redacao@fgv.br; (11) 3799-3717 
leitura da música sendo tocada. O professor, de forma semelhante, deve dar a palavra aos alunos que, em seqüência, devem trazer as suas contribuições para o processo de se chegar a uma melhor solução do caso e o uso correto dos conceitos teóricos.

A melhor avaliação de um professor no método do caso acontece quando ele consegue dos alunos um aprendizado completo, sem falar uma palavra durante a aula; da mesma forma que um maestro não pega um instrumento da orquestra para tocar. 